\title{
Detection of Lotmaria passim, Crithidia mellificae and Replicative Forms of Deformed Wing Virus and Kashmir Bee Virus in the Small Hive Beetle (Aethina tumida)
}

\author{
Antonio Nanetti ${ }^{1}$ (D) James D. Ellis ${ }^{2}$, Ilaria Cardaio ${ }^{1}$ and Giovanni Cilia ${ }^{1, *(D)}$ \\ 1 CREA Research Centre for Agriculture and Environment, Via di Saliceto 80, 40128 Bologna, Italy; \\ antonio.nanetti@crea.gov.it (A.N.); ilaria.cardaio@crea.gov.it (I.C.) \\ 2 Entomology and Nematology Department, University of Florida, 1881 Natural Area Dr., P.O. Box 110620, \\ Gainesville, FL 32607-0620, USA; jdellis@ufl.edu \\ * Correspondence: giovanni.cilia@crea.gov.it; Tel.: +39-051-353-103
}

Citation: Nanetti, A.; Ellis, J.D.; Cardaio, I.; Cilia, G. Detection of Lotmaria passim, Crithidia mellificae and Replicative Forms of Deformed Wing Virus and Kashmir Bee Virus in the Small Hive Beetle (Aethina tumida). Pathogens 2021, 10, 372. https:// doi.org/10.3390/pathogens10030372

Academic Editor: Lawrence S. Young

Received: 16 February 2021

Accepted: 18 March 2021

Published: 19 March 2021

Publisher's Note: MDPI stays neutral with regard to jurisdictional claims in published maps and institutional affiliations.

Copyright: (c) 2021 by the authors. Licensee MDPI, Basel, Switzerland. This article is an open access article distributed under the terms and conditions of the Creative Commons Attribution (CC BY) license (https:// creativecommons.org/licenses/by/ $4.0 /)$.

\begin{abstract}
Knowledge regarding the honey bee pathogens borne by invasive bee pests remains scarce. This investigation aimed to assess the presence in Aethina tumida (small hive beetle, SHB) adults of honey bee pathogens belonging to the following groups: (i) bacteria (Paenibacillus larvae and Melissococcus plutonius), (ii) trypanosomatids (Lotmaria passim and Crithidia mellificae), and (iii) viruses (black queen cell virus, Kashmir bee virus, deformed wing virus, slow paralysis virus, sacbrood virus, Israeli acute paralysis virus, acute bee paralysis virus, chronic bee paralysis virus). Specimens were collected from free-flying colonies in Gainesville (Florida, USA) in summer 2017. The results of the molecular analysis show the presence of L. passim, C. mellificae, and replicative forms of deformed wing virus (DWV) and Kashmir bee virus (KBV). Replicative forms of KBV have not previously been reported. These results support the hypothesis of pathogen spillover between managed honey bees and the $\mathrm{SHB}$, and these dynamics require further investigation.
\end{abstract}

Keywords: honey bee; small hive beetle; invasive pest; trypanosomatids; honey bee virus; deformed wing virus; Kashmir bee virus; replicative virus; strand-specific RT-PCR

\section{Introduction}

Aethina tumida (Murray 1867), the small hive beetle (SHB), is a coleopteran species belonging to the Nitidulidae family [1]. Native to Sub-Saharan Africa [2], it is a destructive, invasive pest of Apis mellifera (western honey bee) colonies [3], and it causes significant damage to brood, pollen, and honey stores [4]. Presently, the SHB is recorded in all continents except Antarctica [3,5-8], having reached North America in 1996; Australia in 2000; and, more recently, countries in Europe, South America, and Asia [9-12]. The SHB is an ecological generalist [4] and creates persistent populations in colonies in areas in which it has been introduced [13].

Honey bees are exposed to pests and pathogens belonging to different groups (viruses, bacteria, fungi, protists, mites, insects, etc.), some of which are responsible for severe health impairment and colony collapse [14-17]. Adult SHBs invade colonies, where they feed, thrive, and reproduce. This allows contact between SHBs and other bee pests and pathogens [18-23].

Lotmaria passim and Crithidia mellificae are two trypanosomatid species capable of colonizing the digestive system of honey bees [24,25]. The transmission is deemed to occur by the oral-fecal route [26,27], and the presence of infected faeces within the hive may promote the circulation of the parasite among worker bees [26]. Both pathogens are deemed to impact colony health by altering bee behavior, physiology, immune response, and lifespan [28-31]. Nevertheless, the details of their pathogenic effects are still not fully understood. Lotmaria passim has been described only recently [25], and it is presently 
acknowledged as the most prevalent $A$. mellifera trypanosomatid [32]. Infections have been reported in Asian, European, and South and North American colonies [8], whereas C. mellificae infections have been rarely observed [8,33-35].

Deformed wing virus (DWV) is a positive-sense ssRNA virus belonging to the Picornaviridae family within the Iflavirus genus [36,37]. Spread globally [32,36-38], three genetic variants have been acknowledged and identified as types $\mathrm{A}, \mathrm{B}$, and C [39,40]. Type $\mathrm{A}$ is by far the most widespread [40], and it may generate asymptomatic or symptomatic infections, the latter including deformed or missing wings, shortened abdomens, and premature bee death [36]. Generally, this virus is transmitted through puncture wounds produced by the ectoparasite Varroa destructor as it feeds on immature honey bees [41]. However, the infection may be transmitted horizontally by bee-to-bee contact, especially in cases of severe infections [42-46], curbicular pollen, bee products, and floral contamination [47-49].

Kashmir bee virus (KBV) is a positive-sense ssRNA virus of the Dicistroviridae family within the Cripavirus genus [50,51], considered endemic in North America and Australia [52,53] but rarely reported in Europe [54-58]. It is genetically related to acute bee paralysis virus (ABPV) [59], and the two may co-infect the same colony or the same individual bee $[59,60]$. Low viral titers are generally detected in subclinical colonies; however, viral replication may be triggered by the presence of stressors, including A. tumida infestations $[46,52,60]$, with a lethal outcome for different honey bee stages [59,61,62]. Ingestion of contaminated brood food $[49,59,63]$ and Varroa feeding behavior [64-66] may elicit the transmission of KBV infections.

Herein, we aimed to assess the presence of the abovementioned pathogens (L. passim, C. mellificae, KBV, and DWV) in addition to pathogenic bacteria (Paenibacillus larvae and Melissococcus plutonius) and other bee viruses (ABPV), Israeli acute paralysis virus (IAPV), black queen cell virus (BQCV), sacbrood virus (SBV), chronic bee paralysis virus (CBPV), and slow paralysis virus (SPV, major and minor)) in SHB specimens collected in Florida, USA in 2017. This is an important first step in determining the role SHBs may plan in the movement of pathogens between honey bee colonies.

\section{Results}

The investigated samples, coming from the same honey bee colony, tested positive for C. mellificae, L. passim, KBV, and DWV (Table 1). No amplicons were detected for P. larvae, M. plutonious, ABPV, IAPV, BQCV, SBV, CBPV, SPV major, and SPV minor in SHB individuals and the pool of SHBs.

Table 1. Summary of the Aethina tumida ( $\mathrm{SHB}=$ small hive beetle) samples that tested positive for a given pathogen with the RT-PCR.

\begin{tabular}{|c|c|c|c|c|c|c|c|c|c|c|c|}
\hline Target & Pool $(n=30)$ & SHB 1 & SHB 2 & SHB 3 & SHB 4 & SHB 5 & SHB 6 & SHB 7 & SHB 8 & SHB 9 & SHB 10 \\
\hline $\begin{array}{l}\text { Crithidia. } \\
\text { mellificae }\end{array}$ & POS & - & - & POS & - & POS & - & - & POS & - & - \\
\hline $\begin{array}{c}\text { Lotmaria } \\
\text { passim }\end{array}$ & POS & - & POS & - & POS & - & POS & - & - & POS & - \\
\hline KBV & POS * & POS * & - & - & - & - & - & - & - & - & POS * \\
\hline DWV & POS * & POS * & POS * & POS * & - & POS * & POS * & - & POS * & POS * & - \\
\hline
\end{tabular}

POS: positive; POS *: positive samples with replicative virus forms.

One of the SHB individuals was negative for all pathogens, whereas the other nine tested positive for one or two of them. The SHB pool was positive for both trypanosomatid species and the two virus types.

In the SHB individuals, no significant difference was found in the prevalence between C. mellificae and L. passim positives (bilateral Fisher's exact test: $p=0.675$ ). No co-infections with the two were detected.

The frequencies of DWV- and KBV-positive individuals did not significantly differ (bilateral Fisher's exact test: $p=0.070$ ). Viral coinfections were found only in one individual 
SHB, representing a significantly lower proportion of the positives (bilateral Fisher's exact test: $p=0.010$ ).

A strand-specific PCR demonstrated active viral replication of KBV and DWV in PCR-positive samples. Blast analysis on the sequences obtained from positive amplicons confirmed the specificity of the results, with high similarity (99\%) to specific virus genome sequences deposited in GenBank. For each virus, the same sequence was recorded in all positive samples. Phylogenetic analysis and pairwise distance analysis indicated the highest homology to DWV type A (Figure 1).

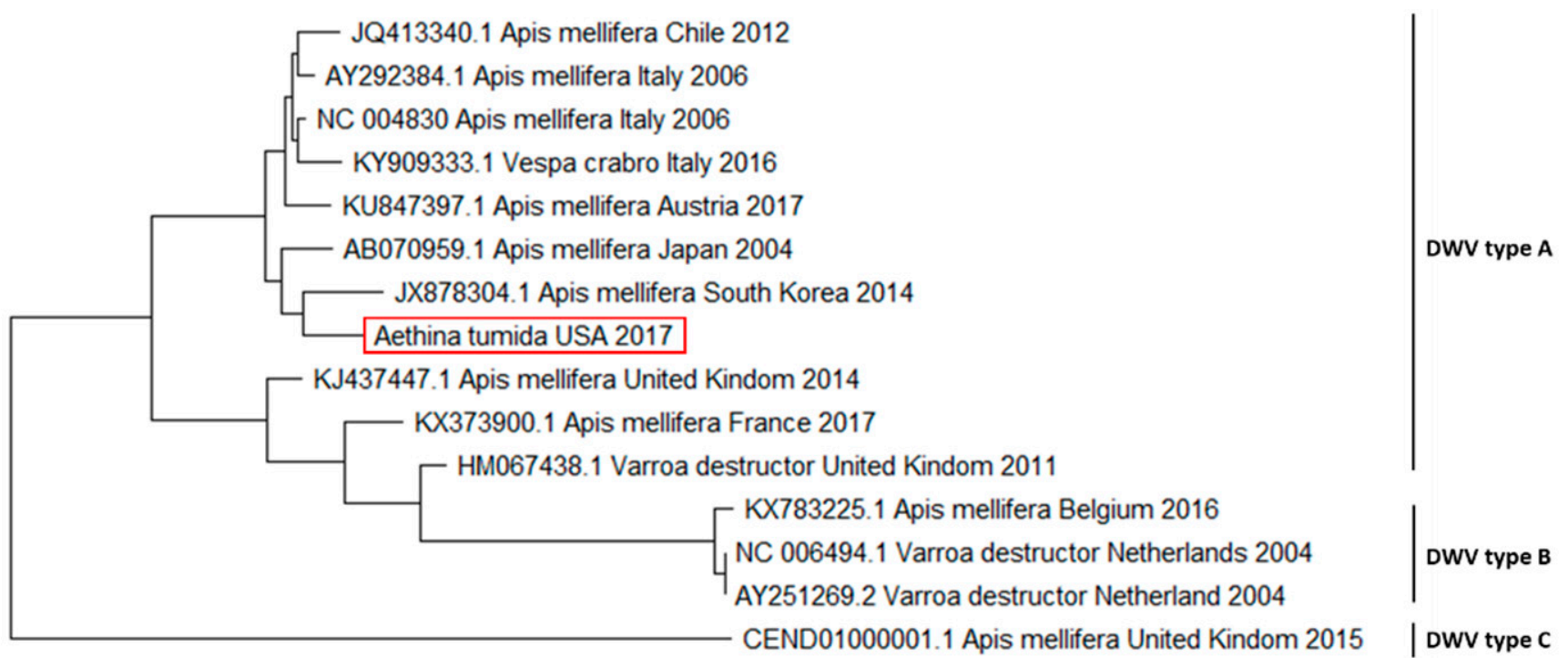

0.050

Figure 1. Molecular phylogenetic analysis for RNA-dependent RNA polymerase of deformed wing virus (DWV) using the maximum likelihood method. The evolutionary history was inferred using the maximum likelihood method based on the Tamura-Nei model. The branch lengths of the tree measured the number of substitutions per site. The analysis involved 28 nucleotide sequences. There were 255 positions in the final dataset. Accession number, host, state, and year of available GenBank DWV sequences are shown. DWV sequence accession numbers are reported and associated with year and site of origin and type. The DWV sequence obtained from the tested Aethina tumida samples is in a red box.

A similar analysis was conducted for the KBV sequence. A close relationship with sequences found in A. mellifera and $V$. destructor from the USA was detected (Figure 2). 


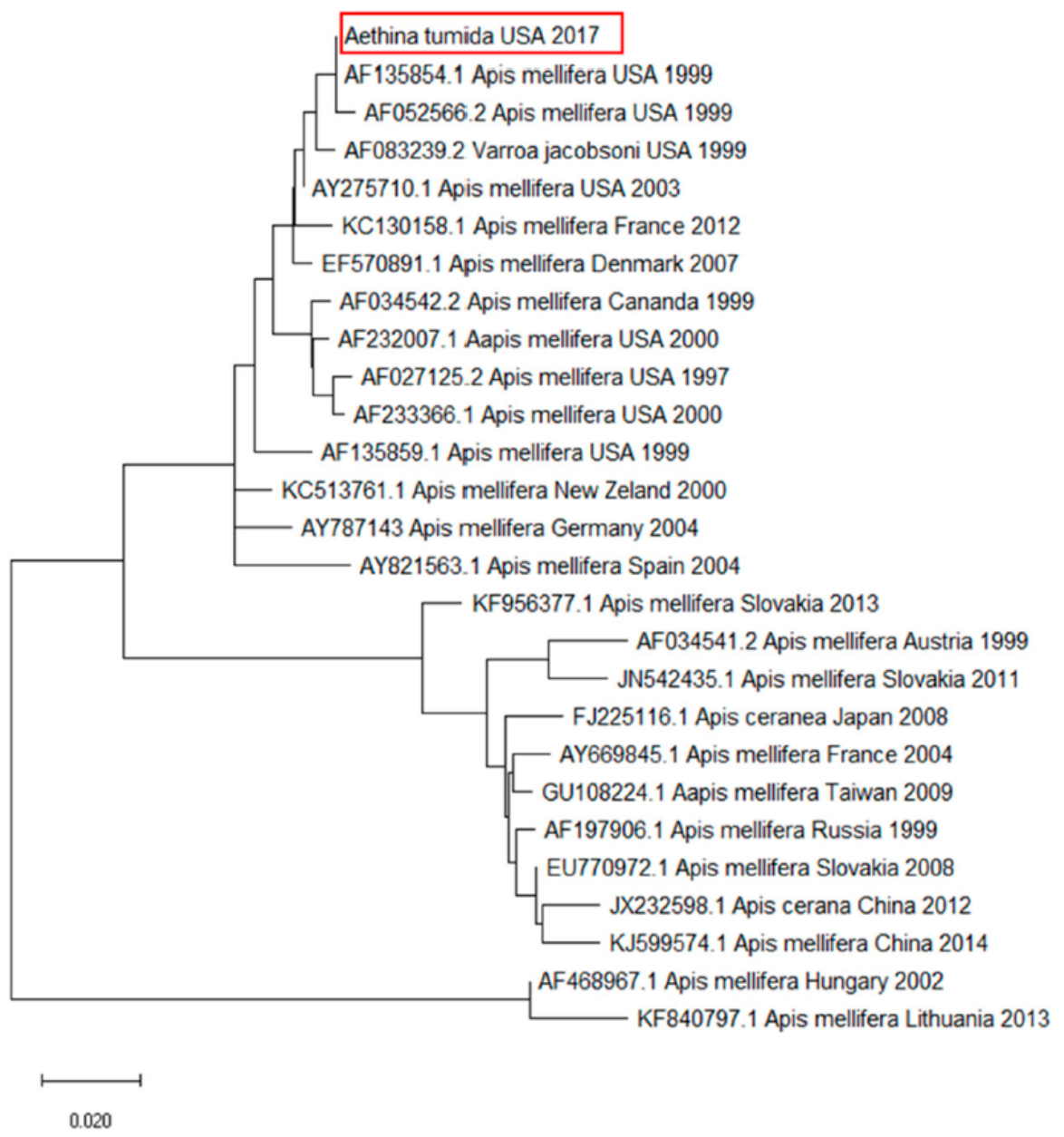

Figure 2. Molecular phylogenetic analysis for RNA-dependent RNA polymerase of Kashmir Bee Virus (KBV) using the maximum likelihood method. The evolutionary history was inferred using the maximum likelihood method based on the Tamura-Nei model. The branch lengths of the tree measured the number of substitutions per site. The analysis involved 35 nucleotide sequences. There were 297 positions in the final dataset. Accession number, host, state, and year of available GenBank KBV sequences are shown. KBV sequence accession numbers are reported and associated with the year and site of origin. The DWV sequence obtained from the tested Aethina tumida samples is in a red box.

\section{Discussion}

To date, only a few instances of individual SHBs bearing bee pathogens have been reported. This is the case for samples from Mexico (positive for L. passim, Apis mellifera filamentous virus (AmFV), C. bombi, Ascosphera apis, and Nosema ceranae [22]), Florida (positive for N. ceranae [20]), and other areas of the USA (positive for DWV, SBV and P. larvae $[19,20,22,24])$.

The present study showed the presence of the honey bee pathogens L. passim, C. mellificae, DWV, and KBV in SHB adults collected from free-flying colonies in Florida. Furthermore, all SHB samples that were positive for DWV and/or KBV contained replicative viral forms. Although DWV replication in SHB adults is not a new finding [18,23], replication of $\mathrm{KBV}$ in $\mathrm{SHBs}$ is.

This is not the first time that DWV and KBV have been reported to infect non-Apis hosts. Replicative DWV was found in hornets (Vespa crabro) [67], Asian hornets (V. velutina) [68], and Argentine ants (Linepithema humile) [69]. Replicative KBV has been found in V. velutina [54], Vespula germanica, and Vespula vulgaris [70-72]. However, the current and previous $[18,23]$ detections on coleopterans suggest that DWV and KBV can infect a 
wide range of potential hosts, thus envisaging a scenario where wild and managed insect species may act as virus reservoirs that fuel reciprocal spillover. Furthermore, the occurrence of replicative DWV and KBV in the same individuals indicates the possibility of viral co-infections in SHBs, as already reported in A. mellifera and other insect species $[59,73,74]$.

The sequence analysis of DWV and KBV resulted in high identity rates to viral sequences identified in A. mellifera. The phylogenetic analysis highlighted that the DWV genome detected in the SHB samples belonged to DWV type A, the less virulent genetic variant of this virus [36]. The KBV genome found in the investigated samples bore a close relationship to other KBV outbreaks reported in the USA, thus excluding the involvement of viruses originating from other countries.

The prevalence of L. passim-positive individuals detected in this study $(40 \%$ of all samples) mirrors that reported in a previous survey in which C. bombi was also reported in larval SHBs [22]. Additionally, we report for the first time SHB samples positive for C. mellificae. Although C. mellificae is generally considered less spread than L. passim in honey bees [33-35], the prevalence levels of the two trypanosomatids in our individual samples did not significantly differ.

None of the samples was positive for P. larvae, M. plutonious, ABPV, IAPV, BQCV, SBV, $\mathrm{CBPV}$, SPV major, or SPV minor. This coincides with the results of previous investigations showing low P. larvae [19] and SBV [21] loads in SHB adults. This likely reflects the health of the colonies that were visited by the SHBs prior to sampling.

The finding results highlight the need to clarify pathogen transmission between honey bees and SHB adults better. In the case of DWV, horizontal transmission occurs chiefly by the oral route [18]. In this regard, SHBs are able to trick honey bee adults into feeding them $[75,76]$, possibly acquiring DWV during the exchange of food via trophallaxis. However, the multifaceted host-parasite interaction [77] allows multiple pathways, including oral-oral and fecal-oral transmission. Adult SHBs also may acquire honey bee pathogens by feeding on bee products that are contaminated with multiple microorganism species [41,47,48,78], cannibalizing bee carcasses, or ingesting infected faeces [78-80].

The articulate interactions above and active flying behavior [8] may bring together adult SHBs of different origins that congregate in the same host colony, generating the detected diversity in the pathogen load. On the other hand, the horizontal transmission may occur bi-directionally, as both SHB adults and larvae might defecate inside the hive [77], potentially spreading infected feces that could transmit and perpetuate infective agents within the colony. Infections may also be transmitted vertically. Bee pathogens may be found in SHB larvae [22,23] as consequences of feeding, environmental contamination, and congenital transmission. Nevertheless, the role that SHBs play in the transmission of honey bee pathogens remains unclear.

\section{Materials and Methods}

\subsection{Sample Collection}

In summer 2017, one honey bee colony of mixed European origin was selected from an experimental apiary of the University of Florida (Gainesville, FL, USA) based on a conspicuous SHB infestation. No evident signs of other diseases could be detected. Forty SHB adults were randomly sampled alive from the colony combs and hive floor. Once in the laboratory, the collected specimens were randomly separated to compose one pool of thirty adults and ten individual beetle samples.

\subsection{Extraction of Total Nucleic Acids}

All the SHBs were washed with $95 \%$ ethanol to remove possible external microbial contaminants. The ethanol was then allowed to evaporate at room temperature.

A TissueLyser II (Qiagen, Hilden, Germany) was used for $3 \mathrm{~min}$ at $25 \mathrm{~Hz}$ to crush all SHB samples in separate $2 \mathrm{~mL}$ Eppendorf tubes filled to the mark with RNase-free water. The resulting suspensions were then split into two equal aliquots from which nucleic acids were extracted (one for DNA and one for RNA). 
DNA and total RNA were extracted with DNeasy Blood \& Tissue Kit (Qiagen) and RNeasy Mini Kit (Qiagen) as previously described [20,67]. All samples were eluted in $30 \mu \mathrm{L}$ DNAase-RNase-free water.

DNA and RNA extracts were stored at $-80^{\circ} \mathrm{C}$ until analysis. High pure sterile DNAand RNA-free water was used as a negative control in all analytical steps.

\subsection{PCR Assays to Detect Bacteria and Protozoa DNA}

The extracted DNA was analyzed by real-time PCR to detect bacteria and trypanosomatids. The primers that were used are reported in Table 2.

For each target gene, a total reaction volume of $15 \mu \mathrm{L}$ was prepared as previously described [81] using 2x QuantiTect Probe PCR Master Mix (Qiagen), forward and reverse primers $(2 \mu \mathrm{M})$, forward and reverse probes $(500 \mathrm{nM})$, and $3 \mu \mathrm{L}$ DNA extract. The real-time PCR assay was performed on a Rotorgene Corbett 6000 (Corbett Research, Sydney, Australia) following the protocols for either gene sequence [54,68]. DNA extracted previously from positive honey bees was used as the positive control for each investigated bacterial and protozoan species.

Table 2. List of primers used to detect bacteria and trypanosomatids in Aethina tumida.

\begin{tabular}{|c|c|c|c|}
\hline Target & Primer Name & Sequence $\left(5^{\prime}-3^{\prime}\right)$ & Reference \\
\hline \multirow{2}{*}{ Paenibacillus larvae } & AFB-F & CTTGTGTTTCTTTCGGGAGACGCCA & \multirow{2}{*}{ [82] } \\
\hline & AFB-R & TCTTAGAGTGCCCACCTCTGCG & \\
\hline \multirow{2}{*}{ Melissococcus plutonius } & MelissoF & CAGCTAGTCGGTTTGGTTCC & \multirow{2}{*}{ [83] } \\
\hline & MelissoR & TTGGCTGTAGATAGAATTGACAAT & \\
\hline \multirow{2}{*}{ Crithida mellificae } & Cmel_Cyt_b_F & TAAATTCACTACCTCAAATTCAATAACATAATCAT & \multirow{2}{*}{ [84] } \\
\hline & Cmel_Cyt_b_R & ATTTATTGTTGTAATCGGTTTTATTGGATATGT & \\
\hline \multirow{2}{*}{ Lotmaria passim } & Lp2F 459 & AGGGATATTTAAACCCATCGAA & \multirow{2}{*}{ [33] } \\
\hline & Lp2R 459 & ACCACAAGAGTACGGAATGC & \\
\hline
\end{tabular}

\subsection{PCR Assays to Detect Virus RNA}

All RNA extracts were retro-transcribed by M-MLV reverse transcriptase (Invitrogen, Carlsbad, CA, USA) using a blend of oligo-d (T) primers and random hexamers following the manufacturer's instruction. Five microliters of the obtained cDNAs were used as a template for the PCR reactions, performed using HotStarTaqPlus Polymerase Mix (Qiagen). Primers to amplify the viral genomes of the honey bee viruses investigated herein are reported in Table 3. The real-time PCR assay was performed on a Rotorgene Corbett 6000. RNA extracted previously from positive honey bees was used as the positive control for each investigated virus.

Table 3. List of primers used to detect viruses in Aethina tumida.

\begin{tabular}{|c|c|c|c|}
\hline Target & Primer Name & Sequence $\left(5^{\prime}-3^{\prime}\right)$ & Reference \\
\hline KBV & $\begin{array}{l}\text { KBV 83F } \\
\text { KBV 161R }\end{array}$ & $\begin{array}{l}\text { ACCAGGAAGTATTCCCATGGTAAG } \\
\text { TGGAGCTATGGTTCCGTTCAG }\end{array}$ & [85] \\
\hline DWV & $\begin{array}{l}\text { DWV Fw } 8450 \\
\text { DWV Rev } 8953\end{array}$ & $\begin{array}{c}\text { TGGCATGCCTTGTTCACCGT } \\
\text { CGTGCAGCTCGATAGGATGCCA }\end{array}$ & [47] \\
\hline $\mathrm{ABPV}$ & $\begin{array}{l}\text { APV 95F } \\
\text { APV 159R }\end{array}$ & $\begin{array}{c}\text { TCCTATATCGACGACGAAAGACAA } \\
\text { GCGCTTTAATTCCATCCAATTGA }\end{array}$ & [85] \\
\hline IAPV & $\begin{array}{l}\text { IAPV B4S0427_R130M } \\
\text { IAPV B4S0427_L17M }\end{array}$ & $\begin{array}{l}\text { RCRTCAGTCGTCTTCCAGGT } \\
\text { CGAACTTGGTGACTTGARGG }\end{array}$ & [86] \\
\hline BQCV & $\begin{array}{l}\text { BQCV 9195F } \\
\text { BQCV 8265R }\end{array}$ & $\begin{array}{l}\text { GGTGCGGGAGATGATATGGA } \\
\text { GCCGTCTGAGATGCATGAATAC }\end{array}$ & [85] \\
\hline
\end{tabular}


Table 3. Cont.

\begin{tabular}{|c|c|c|c|}
\hline Target & Primer Name & Sequence $\left(5^{\prime}-3^{\prime}\right)$ & Reference \\
\hline SBV & $\begin{array}{l}\text { SBV 311F } 79 \\
\text { SBV 380R }\end{array}$ & $\begin{array}{c}\text { AAGTTGGAGGCGCGyAATTG } \\
\text { CAAATGTCTTCTTACdAGAGGyAAGGATTG }\end{array}$ & [85] \\
\hline CBPV & $\begin{array}{l}\text { CPV 304F 79 } \\
\text { CPV 371R }\end{array}$ & $\begin{array}{c}\text { TCTGGCTCTGTCTTCGCAAA } \\
\text { GATACCGTCGTCACCCTCATG }\end{array}$ & [85] \\
\hline SPV major & $\begin{array}{l}\text { SPV 8383F } 81 \\
\text { SPV } 8456 \mathrm{R}\end{array}$ & $\begin{array}{c}\text { TGATTGGACTCGGCTTGCTA } \\
\text { CAAAATTTGCATAATCCCCAGTT }\end{array}$ & [59] \\
\hline SPV minor & $\begin{array}{l}\text { SPV Minor F1 } \\
\text { SPV Minor R1 }\end{array}$ & $\begin{array}{l}\text { ATAGCGCTTTAGTTCAATTGCCAT } \\
\text { CTGGAATATGACCATCACGCAT }\end{array}$ & [38] \\
\hline
\end{tabular}

KBV: Kashmir bee virus; DWV: Deformed wing virus; ABPV: Acute bee paraylis virus; IAPV: Israeli acute bee paryalis virus; BQCV: Black queen cell virus; SBV: Sac brood virus; CBPV: Chronic bee parylis virus; SPV: slow paralysis virus.

\subsection{Strand-Specific RT-PCR}

To evaluate the replication of the detected viruses, strand-specific RT-PCRs were performed using specific primers, as previously described [47]. All cDNAs were amplified by PCR for the related viral target. The amplicons were detected on a $2 \%$ agarose gel, sequenced (BMR Genomics, Padua, Italy), and analyzed using BLAST [87]. Phylogenetic analysis was performed using the maximum likelihood method based on the Tamura-Nei model using MEGA software [88].

\subsection{Statistical Analysis}

The prevalence of the individuals that were positive for C. mellificae or L. passim and of those showing DWV or KBV infections were statistically compared with a bilateral Fisher's exact test under the null hypothesis of equality. The same test was also used to compare the frequency of multiple vs. single viral infections. Due to the small number of samples, the test for independence $\chi^{2}$ was not used in this case.

\section{Conclusions}

This investigation suggests that the honey bee trypanosomatids L. passim and C. mellificae may colonize, and the viruses DWV and KBV successfully infect $A$. tumida adults. Additional studies are needed to determine whether these pathogens generate clinical evidence and signs of infection in SHBs. The horizontal and vertical transmission routes of these pathogens in/between SHBs should also be clarified, as well as the potential, if any, of these pathogens to limit SHB populations in the wild.

Finally, further research is needed to elucidate the epidemiological role that SHBs play in pathogen transmission to honey bees and other insects as a possible dead-end host or vector.

Author Contributions: Conceptualization, G.C.; investigation, G.C.; in-field activity, J.D.E. and I.C.; laboratory activity, G.C.; data curation, G.C. and A.N.; writing-original draft preparation, G.C. and A.N.; writing - review and editing, G.C., J.D.E., I.C. and A.N.; supervision, A.N.; funding acquisition, J.D.E. and A.N. All authors have read and agreed to the published version of the manuscript.

Funding: This research was funded by the Italian Ministry of Agricultural, Food and Forestry Policies, grant number AETHINET ("Monitoraggio e tecniche innovative di diagnosi e di controllo del piccolo coleottero dell'alveare, Aethina tumida") (A.N.) and by a cooperative agreement provided by the United States Department of Agriculture, Animal and Plant Health Inspection Service (USDA-ARS), AP17PPQS\&T00C079 (J.D.E.).

Institutional Review Board Statement: Not applicable.

Informed Consent Statement: Not applicable.

Acknowledgments: The authors are grateful to Brandi and Branden Stanford of the Entomology and Nematology Department, University of Florida, for their valuable technical support. 
Conflicts of Interest: The authors declare no conflict of interest.

\section{References}

1. Murray, A. List of Coleoptera received from Old Calabar. Ann. Mag. Nat. Hist. Lond. 1867, 19, 167-179. [CrossRef]

2. Lundie, A.E. The Small Hive Beetle, Aethina túmida. Sci. Bull. 1940, 220, 40.

3. Schäfer, M.O.; Cardaio, I.; Cilia, G.; Cornelissen, B.; Crailsheim, K.; Formato, G.; Lawrence, A.K.; Le Conte, Y.; Mutinelli, F.; Nanetti, A.; et al. How to slow the global spread of small hive beetles, Aethina tumida. Biol. Invasions 2019, 21, 1451-1459. [CrossRef]

4. Ellis, J.D.; Hepburn, H.R. An ecological digest of the small hive beetle (Aethina tumida), a symbiont in honey bee colonies (Apis mellifera). Insectes Soc. 2006, 53, 8-19. [CrossRef]

5. Al Toufailia, H.; Alves, D.A.; De Bená, D.C.; Bento, J.M.S.; Iwanicki, N.S.A.; Cline, A.R.; Ellis, J.D.; Ratnieks, F.L.W. First record of small hive beetle, Aethina tumida Murray, in South America. J. Apic. Res. 2017, 56, 76-80. [CrossRef]

6. Lee, S.; Hong, K.-J.; Cho, Y.S.; Choi, Y.S.; Yoo, M.-S.; Lee, S. Review of the subgenus Aethina Erichson s. str. (Coleoptera: Nitidulidae: Nitidulinae) in Korea, reporting recent invasion of small hive beetle, Aethina tumida. J. Asia. Pac. Entomol. 2017, 20, 553-558. [CrossRef]

7. Neumann, P.; Pettis, J.S.; Schäfer, M.O. Quo vadis Aethina tumida? Biology and control of small hive beetles. Apidologie 2016, 47, 427-466. [CrossRef]

8. Boncristiani, H.; Ellis, J.D.; Bustamante, T.; Graham, J.; Jack, C.; Kimmel, C.B.; Mortensen, A.; Schmehl, D.R. World Honey Bee Health: The Global Distribution of Western Honey Bee (Apis mellifera L.) Pests and Pathogens. Bee World 2021, 98, 2-6. [CrossRef]

9. Granato, A.; Zecchin, B.; Baratto, C.; Duquesne, V.; Negrisolo, E.; Chauzat, M.-P.; Ribière-Chabert, M.; Cattoli, G.; Mutinelli, F. Introduction of Aethina tumida (Coleoptera: Nitidulidae) in the regions of Calabria and Sicily (southern Italy). Apidologie 2017, 48, 194-203. [CrossRef]

10. da Silva, M.J.V. The First Report Of Aethina tumida In The European Union, Portugal, 2004. Bee World 2014, 91, 90-91. [CrossRef]

11. Palmeri, V.; Scirtò, G.; Malacrinò, A.; Laudani, F.; Campolo, O. A scientific note on a new pest for European honeybees: First report of small hive beetle Aethina tumida, (Coleoptera: Nitidulidae) in Italy. Apidologie 2015, 46, 527-529. [CrossRef]

12. Murilhas, A.M. Aethina tumida arrives in Portugal. Will it be eradicated? EurBee Newsl. 2004, 2, 7-9.

13. Arbogast, R.T.; Torto, B.; Willms, S.; Teal, P.E.A. Trophic habits of Aethina tumida (Coleoptera: Nitidulidae): Their adaptive significance and relevance to dispersal. Environ. Entomol. 2009, 38, 561-568. [CrossRef]

14. McMenamin, A.J.; Genersch, E. Honey bee colony losses and associated viruses. Curr. Opin. Insect Sci. 2015, 8, 121-129. [CrossRef]

15. Brutscher, L.M.; McMenamin, A.J.; Flenniken, M.L. The Buzz about Honey Bee Viruses. PLoS Pathog. 2016, 12, e1005757. [CrossRef]

16. Grupe, A.C.; Quandt, C.A. A growing pandemic: A review of Nosema parasites in globally distributed domesticated and native bees. PLoS Pathog. 2020, 16, e1008580. [CrossRef]

17. Genersch, E.; Evans, J.D.; Fries, I. Honey bee disease overview. J. Invertebr. Pathol. 2010, 103, S2-S4. [CrossRef]

18. Eyer, M.; Chen, Y.P.; Schäfer, M.O.; Pettis, J.; Neumann, P. Small hive beetle, Aethina tumida, as a potential biological vector of honeybee viruses. Apidologie 2009, 40, 419-428. [CrossRef]

19. Schäfer, M.O.; Ritter, W.; Pettis, J.; Neumann, P. Small hive beetles, Aethina tumida, are vectors of Paenibacillus larvae. Apidologie 2010, 41, 14-20. [CrossRef]

20. Cilia, G.; Cardaio, I.; dos Santos, P.E.J.; Ellis, J.D.; Nanetti, A. The first detection of Nosema ceranae (Microsporidia) in the small hive beetle, Aethina tumida Murray (Coleoptera: Nitidulidae). Apidologie 2018, 49, 619-624. [CrossRef]

21. Eyer, M.; Chen, Y.P.; Schäfer, M.O.; Pettis, J.S.; Neumann, P. Honey bee sacbrood virus infects adult small hive beetles, Aethina tumida (Coleoptera: Nitidulidae). J. Apic. Res. 2009, 48, 296-297. [CrossRef]

22. de Landa, G.F.; Porrini, M.P.; Revainera, P.; Porrini, D.P.; Farina, J.; Correa-Benítez, A.; Maggi, M.D.; Eguaras, M.J.; Quintana, S. Pathogens Detection in the Small Hive Beetle (Aethina tumida (Coleoptera: Nitidulidae)). Neotrop. Entomol. 2020, 1-5. [CrossRef]

23. Huwiler, M.; Papach, A.; Cristina, E.; Yañez, O.; Williams, G.R.; Neumann, P. Deformed wings of small hive beetle independent of virus infections and mites. J. Invertebr. Pathol. 2020, 172, 107365. [CrossRef]

24. Arismendi, N.; Caro, S.; Castro, M.P.; Vargas, M.; Riveros, G.; Venegas, T. Impact of Mixed Infections of Gut Parasites Lotmaria passim and Nosema ceranae on the Lifespan and Immune-related Biomarkers in Apis mellifera. Insects 2020, 11, 420. [CrossRef]

25. Schwarz, R.S.; Bauchan, G.R.; Murphy, C.A.; Ravoet, J.; de Graaf, D.C.; Evans, J.D. Characterization of Two Species of Trypanosomatidae from the Honey Bee Apis mellifera: Crithidia mellificae Langridge and McGhee, and Lotmaria passim $\mathrm{n}$. gen., $\mathrm{n}$. sp. J. Eukaryot. Microbiol. 2015, 62, 567-583. [CrossRef]

26. Ruiz- Gonzalez, M.X.; Brown, M.J.F. Honey bee and bumblebee trypanosomatids: Specificity and potential for transmission. Ecol. Entomol. 2006, 31, 616-622. [CrossRef]

27. Runckel, C.; DeRisi, J.; Flenniken, M.L. A Draft Genome of the Honey Bee Trypanosomatid Parasite Crithidia mellificae. PLoS ONE 2014, 9, e95057. [CrossRef] [PubMed]

28. Runckel, C.; Flenniken, M.L.; Engel, J.C.; Ruby, J.G.; Ganem, D.; Andino, R.; DeRisi, J.L. Temporal analysis of the honey bee microbiome reveals four novel viruses and seasonal prevalence of known viruses, Nosema, and Crithidia. PLoS ONE 2011, 6, e020656. [CrossRef] [PubMed] 
29. Ravoet, J.; Maharramov, J.; Meeus, I.; De Smet, L.; Wenseleers, T.; Smagghe, G.; de Graaf, D.C. Comprehensive Bee Pathogen Screening in Belgium Reveals Crithidia mellificae as a New Contributory Factor to Winter Mortality. PLoS ONE 2013, 8, e72443. [CrossRef] [PubMed]

30. Schwarz, R.S.; Evans, J.D. Single and mixed-species trypanosome and microsporidia infections elicit distinct, ephemeral cellular and humoral immune responses in honey bees. Dev. Comp. Immunol. 2013, 40, 300-310. [CrossRef]

31. Strobl, V.; Yañez, O.; Straub, L.; Albrecht, M.; Neumann, P. Trypanosomatid parasites infecting managed honeybees and wild solitary bees. Int. J. Parasitol. 2019, 49, 605-613. [CrossRef]

32. Buendía, M.; Martín-Hernández, R.; Ornosa, C.; Barrios, L.; Bartolomé, C.; Higes, M. Epidemiological study of honeybee pathogens in Europe: The results of Castilla-La Mancha (Spain). Spanish J. Agric. Res. 2018, 16, e0502. [CrossRef]

33. Arismendi, N.; Bruna, A.; Zapata, N.; Vargas, M. PCR-specific detection of recently described Lotmaria passim (Trypanosomatidae) in Chilean apiaries. J. Invertebr. Pathol. 2016, 134, 1-5. [CrossRef]

34. Vargas, M.; Arismendi, N.; Riveros, G.; Zapata, N.; Bruna, A.; Vidal, M.; Rodríguez, M.; Gerding, M. Viral and intestinal diseases detected in Apis mellifera in central and southern Chile. Chil. J. Agric. Res. 2017, 77, 243-249. [CrossRef]

35. Castelli, L.; Branchiccela, B.; Invernizzi, C.; Tomasco, I.; Basualdo, M.; Rodriguez, M.; Zunino, P.; Antúnez, K. Detection of Lotmaria passim in Africanized and European honey bees from Uruguay, Argentina and Chile. J. Invertebr. Pathol. 2019, 160, 95-97. [CrossRef]

36. de Miranda, J.R.; Genersch, E. Deformed wing virus. J. Invertebr. Pathol. 2010, 103, S48-S61. [CrossRef] [PubMed]

37. Genersch, E.; Aubert, M. Emerging and re-emerging viruses of the honey bee (Apis mellifera L.). Vet. Res. 2010, 41, 54. [CrossRef]

38. Martin, S.J.; Highfield, A.C.; Brettell, L.; Villalobos, E.M.; Budge, G.E.; Powell, M.; Nikaido, S.; Schroeder, D.C. Global honey bee viral landscape altered by a parasitic mite. Science 2012, 336, 1304-1306. [CrossRef]

39. Mordecai, G.J.; Wilfert, L.; Martin, S.J.; Jones, I.M.; Schroeder, D.C. Diversity in a honey bee pathogen: First report of a third master variant of the Deformed Wing Virus quasispecies. ISME J. 2016, 10, 1264-1273. [CrossRef]

40. McMahon, D.P.; Natsopoulou, M.E.; Doublet, V.; Fürst, M.; Weging, S.; Brown, M.J.F.; Gogol-Döring, A.; Paxton, R.J. Elevated virulence of an emerging viral genotype as a driver of honeybee loss. Proc. Biol. Sci. 2016, 283, 20160811. [CrossRef]

41. Yue, C.; Schroder, M.; Gisder, S.; Genersch, E. Vertical-transmission routes for deformed wing virus of honeybees (Apis mellifera). J. Gen. Virol. 2007, 88, 2329-2336. [CrossRef] [PubMed]

42. Ball, B.V.; Allen, M.F. The prevalence of pathogens in honey bee (Apis mellifera) colonies infested with the parasitic mite Varroa jacobsoni. Ann. Appl. Biol. 1988, 113, 237-244. [CrossRef]

43. Nordström, S. Distribution of deformed wing virus within honey bee (Apis mellifera) brood cells infested with the ectoparasitic mite Varroa destructor. Exp. Appl. Acarol. 2003, 29, 293-302. [CrossRef] [PubMed]

44. Shen, M.; Cui, L.; Ostiguy, N.; Cox-Foster, D. Intricate transmission routes and interactions between picorna-like viruses (Kashmir bee virus and sacbrood virus) with the honeybee host and the parasitic varroa mite. J. Gen. Virol. 2005, 86, 2281-2289. [CrossRef]

45. Lanzi, G.; de Miranda, J.R.; Boniotti, M.B.; Cameron, C.E.; Lavazza, A.; Capucci, L.; Camazine, S.M.; Rossi, C. Molecular and biological characterization of deformed wing virus of honeybees (Apis mellifera L.). J. Virol. 2006, 80, 4998-5009. [CrossRef]

46. Gisder, S.; Aumeier, P.; Genersch, E. Deformed wing virus: Replication and viral load in mites (Varroa destructor). J. Gen. Virol. 2009, 90, 463-467. [CrossRef]

47. Mazzei, M.; Carrozza, M.L.; Luisi, E.; Forzan, M.; Giusti, M.; Sagona, S.; Tolari, F.; Felicioli, A. Infectivity of DWV Associated to Flower Pollen: Experimental Evidence of a Horizontal Transmission Route. PLoS ONE 2014, 9, e113448. [CrossRef]

48. Mockel, N.; Gisder, S.; Genersch, E. Horizontal transmission of deformed wing virus: Pathological consequences in adult bees (Apis mellifera) depend on the transmission route. J. Gen. Virol. 2011, 92, 370-377. [CrossRef]

49. Chen, Y.; Evans, J.; Feldlaufer, M. Horizontal and vertical transmission of viruses in the honey bee, Apis mellifera. J. Invertebr. Pathol. 2006, 92, 152-159. [CrossRef]

50. de Miranda, J.R.; Cordoni, G.; Budge, G. The Acute bee paralysis virus-Kashmir bee virus-Israeli acute paralysis virus complex. J. Invertebr. Pathol. 2010, 103, S30-S47. [CrossRef]

51. Valles, S.M.; Strong, C.A.; Oi, D.H.; Porter, S.D.; Pereira, R.M.; Vander Meer, R.K.; Hashimoto, Y.; Hooper-Bùi, L.M.; SánchezArroyo, H.; Davis, T.; et al. Phenology, distribution, and host specificity of Solenopsis invicta virus-1. J. Invertebr. Pathol. 2007, 96, 18-27. [CrossRef] [PubMed]

52. Berenyi, O.; Bakonyi, T.; Derakhshifar, I.; Koglberger, H.; Nowotny, N. Occurrence of Six Honeybee Viruses in Diseased Austrian Apiaries. Appl. Environ. Microbiol. 2006, 72, 2414-2420. [CrossRef] [PubMed]

53. Tentcheva, D.; Gauthier, L.; Zappulla, N.; Dainat, B.; Cousserans, F.; Colin, M.E.; Bergoin, M. Prevalence and seasonal variations of six bee viruses in Apis mellifera L. and Varroa destructor mite populations in France. Appl. Environ. Microbiol. 2004, 70, 7185-7191. [CrossRef] [PubMed]

54. Mazzei, M.; Cilia, G.; Forzan, M.; Lavazza, A.; Mutinelli, F.; Felicioli, A. Detection of replicative Kashmir Bee Virus and Black Queen Cell Virus in Asian hornet Vespa velutina (Lepelieter 1836) in Italy. Sci. Rep. 2019, 9, 1-9. [CrossRef]

55. Cersini, A.; Bellucci, V.; Lucci, S.; Mutinelli, F.; Granato, A.; Porrini, C.; Felicioli, A.; Formato, G. First isolation of Kashmir bee virus (KBV) in Italy. J. Apic. Res. 2013, 52, 54-55. [CrossRef]

56. Porrini, C.; Mutinelli, F.; Bortolotti, L.; Granato, A.; Laurenson, L.; Roberts, K.; Gallina, A.; Silvester, N.; Medrzycki, P.; Renzi, T.; et al. The Status of Honey Bee Health in Italy: Results from the Nationwide Bee Monitoring Network. PLoS ONE 2016, 11, e0155411. [CrossRef]

57. Siede, R.; Büchler, R. First detection of Kashmir bee virus in Hesse, Germany. Berl. Munch. Tierarztl. Wochenschr. 2004, 117, 12-15. 
58. Ward, L.; Waite, R.; Boonham, N.; Fisher, T.; Pescod, K.; Thompson, H.; Chantawannakul, P.; Brown, M. First detection of Kashmir bee virus in the UK using real-time PCR. Apidologie 2007, 38, 181-190. [CrossRef]

59. de Miranda, J.R.; Dainat, B.; Locke, B.; Cordoni, G.; Berthoud, H.; Gauthier, L.; Neumann, P.; Budge, G.E.; Ball, B.V.; Stoltz, D.B. Genetic characterization of slow bee paralysis virus of the honeybee (Apis mellifera L.). J. Gen. Virol. 2010, 91, 2524-2530. [CrossRef]

60. Evans, J.D. Genetic Evidence for Coinfection of Honey Bees by Acute Bee Paralysis and Kashmir Bee Viruses. J. Invertebr. Pathol. 2001, 78, 189-193. [CrossRef]

61. Pettis, J.; Van Engelsdorp, D.; Cox-Foster, D. Colony collapse disorder working group pathogen sub-group progress report. Am. Beе J. 2007, 103, 595-597.

62. Todd, J.H.; De Miranda, J.R.; Ball, B.V. Incidence and molecular characterization of viruses found in dying New Zealand honey bee (Apis mellifera) colonies infested with Varroa destructor. Apidologie 2007, 38, 354-367. [CrossRef]

63. Chen, Y.P.; Siede, R. Honey Bee Viruses. Adv. Virus Res. 2007, 70, 33-80.

64. Shen, M.; Yang, X.; Cox-Foster, D.; Cui, L. The role of varroa mites in infections of Kashmir bee virus (KBV) and deformed wing virus (DWV) in honey bees. Virology 2005, 342, 141-149. [CrossRef]

65. Hung, A.C.F. PCR detection of Kashmir bee virus in honey bee excreta. J. Apic. Res. 2000, 39, 103-106. [CrossRef]

66. Hung, A.C.F.; Shimanuki, H. A scientific note on the detection of Kashmir bee virus in individual honeybees and Varroa jacobsoni mites. Apidologie 1999, 30, 353-354. [CrossRef]

67. Forzan, M.; Sagona, S.; Mazzei, M.; Felicioli, A. Detection of deformed wing virus in Vespa crabro. Bull. Insectology 2017, 70, 261-265.

68. Mazzei, M.; Forzan, M.; Cilia, G.; Sagona, S.; Bortolotti, L.; Felicioli, A. First detection of replicative deformed wing virus (DWV) in Vespa velutina nigrithorax. Bull. Insectology 2018, 71, 211-216.

69. Sébastien, A.; Lester, P.J.; Hall, R.J.; Wang, J.; Moore, N.E.; Gruber, M.A.M. Invasive ants carry novel viruses in their new range and form reservoirs for a honeybee pathogen. Biol. Lett. 2015, 11, 20150610. [CrossRef]

70. Anderson, D.L. Kashmir bee virus: A relatively harmless virus of honey bee colonies. Am. Bee J. 1991, 131, 767-771.

71. Quinn, O.; Gruber, M.A.M.; Brown, R.L.; Baty, J.W.; Bulgarella, M.; Lester, P.J. A metatranscriptomic analysis of diseased social wasps (Vespula vulgaris) for pathogens, with an experimental infection of larvae and nests. PLoS ONE 2018, 13, e0209589. [CrossRef] [PubMed]

72. Singh, R.; Levitt, A.L.; Rajotte, E.G.; Holmes, E.C.; Ostiguy, N.; vanEngelsdorp, D.; Lipkin, W.I.; dePamphilis, C.W.; Toth, A.L.; Cox-Foster, D.L. RNA Viruses in Hymenopteran Pollinators: Evidence of Inter-Taxa Virus Transmission via Pollen and Potential Impact on Non-Apis Hymenopteran Species. PLoS ONE 2010, 5, e14357. [CrossRef] [PubMed]

73. Evans, J.D.; Schwarz, R.S. Bees brought to their knees: Microbes affecting honey bee health. Trends Microbiol. 2011, 19, 614-620. [CrossRef] [PubMed]

74. Hung, A.C.; Adams, J.R.; Shimanuki, H. Bee parasitic mite syndrome. (II). The role of Varroa mite and viruses. Am. Bee J. 1995, $135,702-704$.

75. Ellis, J.D.; Pirk, C.W.W.; Hepburn, H.R.; Kastberger, G.; Elzen, P.J. Small hive beetles survive in honeybee prisons by behavioural mimicry. Naturwissenschaften 2002, 89, 326-328. [CrossRef]

76. Ellis, J.D. Reviewing the confinement of small hive beetles (Aethina tumida) by western honey bees (Apis mellifera). Bee World 2005, 86, 56-62. [CrossRef]

77. Cuthbertson, A.G.S.; Wakefield, M.E.; Powell, M.E.; Marris, G.; Anderson, H.; Budge, G.E.; Mathers, J.J.; Blackburn, L.F.; Brown, M.A. The small hive beetle Aethina tumida: A review of its biology and control measures. Curr. Zool. 2013, 59, 644-653. [CrossRef]

78. Chen, Y.P.; Pettis, J.S.; Collins, A.; Feldlaufer, M.F. Prevalence and Transmission of Honeybee Viruses. Appl. Environ. Microbiol. 2006, 72, 606-611. [CrossRef]

79. Gusachenko, O.N.; Woodford, L.; Balbirnie-Cumming, K.; Ryabov, E.V.; Evans, D.J. Evidence for and against deformed wing virus spillover from honey bees to bumble bees: A reverse genetic analysis. Sci. Rep. 2020, 10, 16847. [CrossRef]

80. Felicioli, A.; Forzan, M.; Sagona, S.; D’Agostino, P.; Baido, D.; Fronte, B.; Mazzei, M. Effect of oral administration of 1,3-1,6 $\beta$-glucans in DWV naturally infected newly emerged bees (Apis mellifera L.). Vet. Sci. 2020, 7, 52. [CrossRef]

81. Cilia, G.; Garrido, C.; Bonetto, M.; Tesoriero, D.; Nanetti, A. Effect of Api-Bioxal ${ }^{\circledR}$ and ApiHerb ${ }^{\circledR}$ Treatments against Nosema ceranae Infection in Apis mellifera Investigated by Two qPCR Methods. Vet. Sci. 2020, 7, 125. [CrossRef]

82. Dobbelaere, W.; de Graaf, D.C.; Peeters, J.E. Development of a fast and reliable diagnostic method for American foulbrood disease (Paenibacillus larvae subsp. larvae) using a $16 S$ rRNA gene based PCR. Apidologie 2001, 32, 363-370. [CrossRef]

83. Roetschi, A.; Berthoud, H.; Kuhn, R.; Imdorf, A. Infection rate based on quantitative real-time PCR of Melissococcus plutonius, the causal agent of European foulbrood, in honeybee colonies before and after apiary sanitation. Apidologie 2008, 39, 362-371. [CrossRef]

84. Xu, G.; Palmer-Young, E.; Skyrm, K.; Daly, T.; Sylvia, M.; Averill, A.; Rich, S. Triplex real-time PCR for detection of Crithidia mellificae and Lotmaria passim in honey bees. Parasitol. Res. 2018, 117, 623-628. [CrossRef]

85. Chantawannakul, P.; Ward, L.; Boonham, N.; Brown, M. A scientific note on the detection of honeybee viruses using real-time PCR (TaqMan) in Varroa mites collected from a Thai honeybee (Apis mellifera) apiary. J. Invertebr. Pathol. 2006, 91, 69-73. [CrossRef]

86. Kajobe, R.; Marris, G.; Budge, G.; Laurenson, L.; Cordoni, G.; Jones, B.; Wilkins, S.; Cuthbertson, A.G.S.; Brown, M.A. First molecular detection of a viral pathogen in Ugandan honey bees. J. Invertebr. Pathol. 2010, 104, 153-156. [CrossRef] 
87. Altschul, S.F.; Gish, W.; Miller, W.; Myers, E.W.; Lipman, D.J. Basic local alignment search tool. J. Mol. Biol. 1990, 215, 403-410. [CrossRef]

88. Kumar, S.; Stecher, G.; Li, M.; Knyaz, C.; Tamura, K. MEGA X: Molecular Evolutionary Genetics Analysis across Computing Platforms. Mol. Biol. Evol. 2018, 35, 1547-1549. [CrossRef] 